УДК 797.12.015

DOI https://doi.org/10.26661/2663-5925-2021-3-10

\title{
СПЕЦАЛЬНА ФІЗИЧНА ПІДГОТОВКА ВЕСЛУВАЛЬНИКІВ ВИСОКОЇ КВАЛІФІКАЦІЇ В ПІДГОТОВЧИЙ ПЕРІОД СПОРТИВНОГО ТРЕНУВАННЯ
}

\author{
Клопов Р. В. \\ доктор педагогічних наук, професор \\ Запорізький національний університет \\ вул. Жуковського, 66, Запоріжжя, Украӥна \\ orcid.org/0000-0001-9036-4331 \\ clopov-r@ukr.net
}

Тищенко В. О.

доктор наук з фізичного виховання і спорту, професор, професор кафедри теорії та методики фізичної культури і спорту

Запорізький національний університет

вул. Жуковського, 66, Запоріжжя, Украӥна

orcid.org/0000-0002-9540-9612

valeri-znu@ukr.net

Меснянкін Д. Г.

студент магістратури

факультету фізичного виховання здоров'я та туризму

Запорізький національний університет

вул. Жуковського, 66, Запоріжжя, Украӥна

dimames1811@gmail.com

Ключові слова: силові якості, функиіональна підготовленість підготовчій період, контрольні тестування, роботоздатність.
Визначено та проаналізовано проблеми вдосконалення спеціальної силової і функціональної підготовленості веслувальників високої кваліфікації у підготовчій період спортивного тренування в академічному веслуванні. Рівень ефективності змагальної діяльності у веслуванні академічному прямо залежить від рівня спеціальної фізичної підготовленості для результативного подолання двох кілометрів змагальної дистанції, яка є стандартною і використовується на міжнародних змаганнях та на Олімпійських іграх. У дослідженні взяли участь 6 веслувальників високої кваліфікації віком від 17 до 23 років. Метою дослідження було розробити та експериментально перевірити програму спеціальної силової і функціональної підготовленості веслувальників високої кваліфікації у підготовчому періоді. Для оцінки рівня спеціальної підготовленості використовують методи контрольних тестувань. Впродовж експерименту на початку та наприкінці було проведено контроль спеціальної силової підготовленості у тренажерному залі, максимальна вага на таких вправах як, тяга штанги лежачі і присідання зі штангою на плечах, функціональної підготовленості на веслувальному ергометрі «Concept 2», у вигляді 2000 метрів та 5000 метрів. Основним показником результативності на ергометрі була середня потужність проходження дистанції, а у тренажерному залі - кілограми. У ході дослідження було зафіксовано підвищення рівня спеціальної фізичної підготовленості. Наприкінці тренувальної програми, спрямованої на вдосконалення спеціальної фізичної підготовленості, було проведено статистичну обробку отриманих даних за критерієм Стьюдента та Фішера, які 
констатують статистично значуще зростання рівня спеціальної силової і функціональної підготовленості веслувальників високої кваліфікації у підготовчому періоді та підтверджують ефективність запропонованої нами експериментальної програми тренувань.

\title{
SPECIAL EXERCISE CONDITIONING OF THE TRAINING OF HIGHLY-QUALIFIED ROWERS IN THE PREPARATORY PERIOD OF ATHLETIC SESSION
}

\author{
Klopov R. V. \\ Doctor of Pedagogical Sciences, Professor \\ Zaporizhzhya National University \\ Zhukovskogo str., 66, Zaporizhzhya, Ukraine \\ orcid.org/0000-0001-9036-4331 \\ clopov-r@ukr.net
}

Tyshchenko V. O.

Doctor of Sciences in Physical Education and Sports, Professor,

Professor at the Department of Theory and Methods

of Physical Culture and Sports

Zaporizhzhia National University

Zhukovskoho str., 66, Zaporizhzhia, Ukraine

orcid.org/0000-0002-9540-9612

valeri-znu@ukr.net

Mesniankin D.

Master's Student

Faculty of Physical Education, Health and Tourism

Zaporizhzhya National University

Zhukovskogo str., 66, Zaporizhzhya, Ukraine

dimames1811@gmail.com

Key words: strength qualities, functional readiness, preparatory period, control tests, operability.
The problems of inspiration of special strength and functional training of highly qualified rowers and preparation of the period of sports training in academic rowing are determined and analyzed. The level of effectiveness of competitive activities in academic rowing directly depends on the level of special physical fitness to effectively overcome two kilometers of competitive distance, which is standard and used in international competitions and the Olympic Games. The study involved 6 highly qualified rowers aged 17 to 23 years. The purpose of the study was to develop and experimentally test the program of special strength and functional training of highly qualified rowers in the preparatory period. Control methods are used to assess the level of special training. During the experiment, at the beginning and at the end, the control of special strength training in the gym, maximum weight in such exercises as, barbell traction lying and squats with a barbell on the shoulders, and functional training on a rowing ergometer Concept 2, in the form of 2000 meters and 5000 meters. The main indicator of performance on the ergometer was the average power of the distance, and in the gym - kilograms. During the study, an increase in the level of special physical fitness was recorded. At the end of the training program aimed at improving special physical fitness, statistical data were processed according to Student and Fisher criteria, which state a statistically significant increase in the level of special strength and 
functional training of highly qualified rowers in the preparatory period, and confirm the effectiveness of our proposed experiment.

Постановка проблеми. Підвищення рівня розвитку функціональних можливостей спортсмена сьогодні $є$ найважливішою складовою частиною тренувального процесу та грає велику роль у досяганні найвищих результатів в академічному веслуванні. Для розгортання та поглибленого аналізу такою проблемою займаються Дяченко А., Довгодько I., Федотов А. та інші науковці та тренери $[1 ; 2 ; 3]$. Для досягання мети проводиться багато опрацьовування, аналізування та корегування тренувальних планів. У провідних країнах світу з академічного веслування, таких як Німеччина, Нідерланди, Італія, Нова Зеландія, Румунія, в них приділяється багато часу та зусиль, а іноді і залучення кращих спортивних умів світу для того, щоб досягти найвищих результатів. У наш час Україна всупереч усім несприятливим факторам може досягати сходинок п'єдесталу, але конкурентоздатність світової арени вимагає від наших спортсменів вищої кваліфікації, плідної праці та раціонально поставленого тренувального плану. Зараз у цей непростий час епідемії COVID-19 спортсмени всього світу не мали можливості тренуватися у команді у зв'язку з карантином та 3 перенесенням Олімпійських ігор на 2021 рік, вони не втратили волю до перемоги та здобуття нових вершин. У цей час зміни поколінь спортсменів наші тренери з усіх сил намагаються зібрати команди, які зможуть гідно представляти нашу країну на світовій арені. Великий внесок у дослідження спеціальної фізичної підготовки, зробили: Дяченко А., Довгодько I., Лисенко О., Федотов А., Виноградов В., Русанова О., Павлік А. та багато інших науковців [4-9]. У дослідженнях Дяченко А., Довгодько І., було представлено проблему передстартової підготовки веслувальників високої кваліфікації, обгрунтування підходів до тренувальних засобів, раціональне планування тренувального процесу для стимуляції працездатності веслувальників високої кваліфікації [4].

У дослідженнях Дяченка А., Лисенка О., Виноградова В. було визначено реакції щодо впливу на працездатність на початку, в середині i в заключній частині дистанції: аеробного та анаеробного енергозабезпечення роботи, розгортання споживання кисню, ступеню стійкості кардіореспіраторної системи під час ацидозу, здатності мати анаеробний резерв на другій половині дистанції і його реалізації на фініші. Були представлені дані, які дозволили оцінити рівень спеціальної фізичної підготовленості веслувальників високої кваліфікації і визначити функціональні можливості, які забезпечують проходження змагальної дистанції [5].
У публікації Федотова А., Дяченка А. виявлено аналіз використання показників спеціальної роботоздатності для оцінки витривалості веслувальників високої кваліфікації, аналіз спеціальної витривалості на основі навантаження інтегральних функціональних властивостей організму [6]. Авторами наукових досліджень доведено, що високий рівень функціональних можливостей організму $є$ однією 3 головних умов досягання максимально можливих результатів. Плідна праця та раціональна побудова тренувального процесу дозволять підвищити рівень функціональних можливостей та рухових якостей веслувальників.

Мета, завдання та методи дослідження. Мета статті - розробити та експериментально перевірити програму спеціальної силової і функціональної підготовленості веслувальників високої кваліфікації в підготовчому періоді.

Під час цієї програми були використані такі методи: 1) аналіз та узагальнення літературних джерел. Вивчення та поглиблений аналіз літературних джерел з проблеми розвитку фізичної підготовки веслувальників високої кваліфікації, та використання їх у дослідженні; 2) педагогічний експеримент. Оцінка рівня силової та функціональної підготовленості веслувальників високої кваліфікації у підготовчій період після виконання експериментальної програми; 3 ) методи контрольних тренувань (тестування). Перевірка ефективності експериментальної програми із застосуванням контрольних тестів: максимальної сили та тестів на ергометрі: 5000 м та 2000 м, розробленої для веслувальників високої кваліфікації; 4) пульсометрія. Застосування пульсометра «Polar» для отримання даних анаеробного порогу і корекції тренувального навантаження для веслувальників високої кваліфікації; 5) методи математичної статистики (критерій Ст'юдента, критерій Фішера).

Експериментальна програма спрямована на вдосконалення спеціальної фізичної підготовленості веслувальників високої кваліфікації та базується на експериментальній побудові тренувального процесу веслувальників високої кваліфікації, розробленої та впровадженої нами у період жовтень 2020 - квітень 2021 року.

У дослідженні брали участь 6 спортсмени високої кваліфікації (КМС, МС) 3 академічного веслування.

Виклад основного матеріалу. Розроблена тренувальна програма має 6 мезоциклів, які включають у себе 2 мезоцикла, спрямовані на вдосконалення сили та швидкісно-силових якостей веслувальника, i 4 мезоцикла, спрямовані на вдосконалення спеціальної фізичної підготовлено- 
сті та функціональних можливостей спортсмена. Форма тренувань: 6 днів на тиждень по 1 тренувальному заняттю на день. Форма тренувань: день - веслування на ергометрі, день - тренажерний зал. Перед впровадженням експериментальної програми було проведено ряд попередніх тестувань: максимальна сила: тяга лежачі, присідання зі штангою, контрольне проходження дистанції на ергометрі 2000 м та 5000 м, які дали змогу оцінити рівень спеціальної фізичної підготовленості спортсменів на момент впровадження програми. Головним показником максимальної сили були кілограми на штанзі, а на ергометрі основним показником були середні вати (потужність) кожного спортсмена і середня частота серцевих скорочень для оцінки функціональних можливостей веслувальників. Експериментальна програма тренувань розділена на 2 частини, до нового року та після. Початок експериментальної програми починається 3 мезоцилка, спрямованого на вдосконалення силових та швидкісно-силових якостей, які включають в себе 3 ударних мікроцикла та 1 відновлювальний. Кількість тренувальних часів, зазначених на вдосконалення сили, $-45 \%$, на вдосконалення швидкісно-силових якостей - 45\%, та на відновлення - 10\%, з усього тренувального часу мезоцикла. Це надає змогу спортсмену підвищити рівень м'язової маси, підвищити швидкісний рівень рухових дії та відновитися і мати гарне самопочуття перед наступним мезоциклом. У програму відновлювального мікроциклу входить тренування в аеробному режимі, при низьких показниках частоти серцевих скорочень, гідропроцедури та масаж розігрівальними мазями. У програму мезоциклу, спрямованого на вдосконалення силових та швидкісно-силових якостей, входять тренувальні заняття на веслувальному ергометрі (рис. 1) та у тренажерному залі. Вправи у тренажерному залі мають класичний силовий напрям 6-10 підходів по 6-8 повторень. На ергометрі за основу взяті вправи, які виконують на низькому темпі рухів - 12-20 для розвитку силі, та на показниках 8-10 на барабані ергометра (рис. 2). Таким чином регулюється супротив, від 1 до 10. Трену- вання спрямовані на розвиток швидкісно-силових якостей, виконуються незалежно від темпу рухів, а на максимально можливому темпі та на показниках 8-10 спротиву барабана ергометра. Величина навантаження 85-100\% від максимуму.

Після мезоциклу, спрямованого на вдосконалення силових та швидкісно-силових якостей, експериментальна програма включає в себе мезоцикл, спрямований на вдосконалення спеціальної фізичної підготовленості та функціональних можливостей спортсмена, який містить у собі 3 ударних i 1 відновлювальний мікроцикл. Кількість тренувальних часів, відведених на спеціальну фізичну підготовленість у тренажерному залі, $-40 \%$, на спеціальну витривалість на ергометрі - 45\%, та на відновлення - 10\% з усього тренувального часу мезоциклу. Головним способом вдосконалення спеціальної фізичної підготовленості у тренажерному залі є вправи: 6-8 підходів по 20-30 повторень. Вправи на веслувальному ергометрі виконуються на довільному темпі рухів та на показниках спротиву барабана 6-8, для вдосконалення спеціальної витривалості, базуються на основі тривалих та коротких дистанцій, для підвищення рівня функціональних можливостей та розгортання анаеробних процесів, величина навантаження яких регулюється показниками ЧСС. У цьому мезоциклі ми провели проміжний контроль, моделювання змагальної дистанції 2000 м. На жаль, цей контроль не дав значного приросту результату, але ми скорегували тренувальну програму таким чином, що вона розрахована на тривалий час, і очікувати значного результату не варто, але нам потрібно було побачити мінімальні зрушення в позитивну сторону. Завершує першу частину експериментальної програми теж мезоцикл, спрямований на вдосконалення спеціальної фізичної підготовленості та спеціальної витривалості, який містить в собі 4 ударних і 1 відновлювальний мікроцикл. Незважаючи на те, що заключний мезоцикл 1 частини експериментальної програми спрямований на ті ж самі якості, що і попередній, він супроводжується більшими об' ємами тренувальних занять і містить на 1 ударний мікроцикл більше.

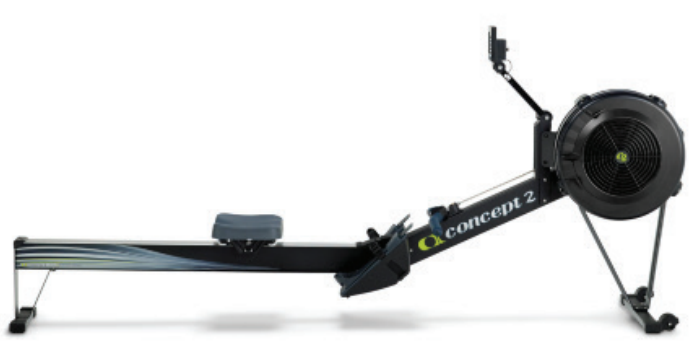

Рис. 1. Веслувальний ергометр «Concept 2»

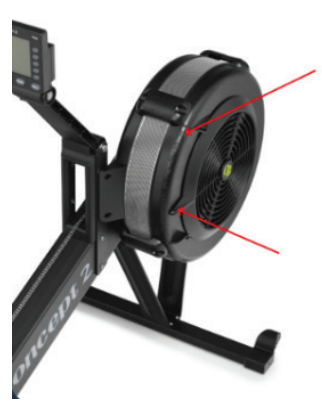

Рис. 2. Налаштування спротиву барабана 
Друга частина експериментальної програми включає в себе 1 мезоцикл, спрямований на вдосконалення силових та швидкісно-силових якостей, і 2 мезоцикли, спрямовані на вдосконалення спеціальної фізичної підготовленості та функціональних можливостей спортсмена. Незважаючи на те, що структура мезоциклів другої частини має ту ж саму спрямованість, вона супроводжується більшою кількістю ударних мікроциклів (1-2), які впливають на підвищення роботоздатності веслувальників. Після виконання експериментальної програми тренувальних занять спортсмени, які брали участь у нашому дослідженні, показали динаміку змін у результатах контролю. Ми провели етапні контролі: максимальна сила: тяга лежачі, присідання зі штангою, контрольне проходження дистанції на ергометрі 2000 м та 5000 м.

Результати тестів на ергометрі та максимальної сили перед та після впровадження експериментальної програми значно відрізняються. Етапний контроль силових якостей найширших м'язів спини та чотириголових м'язів стегна 3 вправи тяга лежачі та присідань зі штангою показує, що силові якості цих м'язів веслувальників зросли 3 вправи тяга лежачі в середньому на $6,35 \pm 0,48 \%$, а

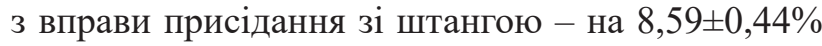
у кілограмах відповідно (табл. 1). Враховуючи те, що рівень силових якостей у веслувальників грає найменшу роль 3 усіх основних якостей, ці показники, на перший погляд, не значні, але є результатом експериментальної програми.

Другий контроль - моделювання змагальної дистанції в 5000 м для оцінки рівня спеціальної витривалості на веслувальному ергометрі. Така експериментальна програма тренувань підвищила рівень функціональних можливостей організму веслувальників після виконання повного обсягу програми, а саме спеціальну витривалість. Як ви можете побачити, середня потужність проходження дистанції 5000 м зросла внаслідок підвищення рівня анаеробної витривалості. У середньому рівень потужності підвищився на $5,9 \pm 3,99 \%$ (табл. 2). Частота серцевих скорочень залишилась без змін. Не всі веслувальники значно підвищили свої результати, для більшого ефекту треба корекція тренувальної програми для кожного спортсмена.

Заключний, третій контроль - моделювання змагальної дистанції 2000 м на ергометрі. Цей контроль $€$ основним, тому що веслувальники змагаються на 2000 м на воді. Такий вид контролю включає в себе всі ті якості, про які ми казали вище. Як ви можете побачити, середня потужність проходження дистанції 2000 м зросло в середньому на 7,9 $93,67 \%$ (табл. 3). Частота серцевих скорочень залишилась без змін.

Для перевірки ефективності запропонованої програми спеціальної силової і функціональної підготовленості веслувальників високої кваліфікації у підготовчому періоді було проведено статистичну обробку отриманих даних. На першому етапі обробки було встановлено, що вибірка даних за показниками асиметрії (A) й ексцесу (Е) $\epsilon$ нормально розподіленою. На другому етапі була проведена перевірка рівності дисперсій даних за критерієм Фішера (F). F емпіричне $1,424 \leq \mathrm{F}$ табл. $1,438(\mathrm{P}=0,05)$. Тому

Таблиця 1

Порівняльний аналіз змін силових якостей найширших м'язів спини та м'язів стегна у вправах: тяга штанги лежачі, присідання зі штангою на плечах, за період педагогічного експерименту (кг, \%)

\begin{tabular}{|l|c|c|}
\hline \multicolumn{1}{|c|}{ Етапи експерименту } & $\begin{array}{c}\text { Силові якості найширших м'язів } \\
\text { спини, кг }\end{array}$ & Силові якості м'язів стегна, кг \\
\hline На початку & $79,1 \pm 5,84$ & $116,6 \pm 6,05$ \\
\hline Наприкінці & $84,1 \pm 5,84$ & $126,6 \pm 6,05$ \\
\hline Динаміка змін, \% & $6,35 \pm 0,48$ & $8,59 \pm 0,44$ \\
\hline
\end{tabular}

Таблиця 2

Порівняльний аналіз змін потужності під час проходження тесту 5000 м на ергометрі за період педагогічного експерименту (вт, \%)

\begin{tabular}{|l|c|}
\hline \multicolumn{1}{|c|}{ Етапи експерименту } & Потужність, вт \\
\hline На початку & $268,8 \pm 14,07$ \\
\hline Наприкінці & $285,2 \pm 21,96$ \\
\hline Динаміка змін, \% & $5,9 \pm 3,99$ \\
\hline
\end{tabular}


Таблиця 3

Порівняльний аналіз змін потужності під час проходження тесту 2000 м на ергометрі за період педагогічного експерименту (вт, \%)

\begin{tabular}{|l|c|}
\hline \multicolumn{1}{|c|}{ Етапи експерименту } & Потужність, вт \\
\hline На початку & $307,2 \pm 31,3$ \\
\hline Проміжний контроль & $308,4 \pm 31$ \\
\hline Наприкінці & $331,6 \pm 31,9$ \\
\hline Динаміка змін, \% & $7,9 \pm 3,67$ \\
\hline
\end{tabular}

можна зробити висновок про однорідність дисперсій. Був проведений i кореляційний аналіз експериментальних даних, який показав позитивну кореляцію $\mathrm{R}=0,63$. У зв'язку з вищезазначеним було обрано для порівняльного аналізу зв'язаних вибірок параметричний критерій Стьюдента. Порівняльний статистичний аналіз експериментальних даних показав вірогідні відмінності між показниками на початку та наприкінці педагогічного експерименту щодо впровадження запропонованої програми спеціальної силової і функціональної підготовленості веслувальників високої кваліфікації у підготовчому періоді (t розрахункове - 3,03 при рівні значущості $\mathrm{P} \leq 0,05)$.

Отже, констатуємо статистично значуще зростання рівня спеціальної силової і функціональної підготовленості веслувальників високої кваліфікації в підготовчому періоді.
Висновки. Експериментальна програма, за якою тренувались веслувальники високої кваліфікації у підготовчій період, довела свою ефективність. Всі спортсмени вірогідно підвищили свої функціональні можливості після виконання такої програми тренувань, але програма спеціальної силової і функціональної підготовки веслувальників потребує ретельного аналізу та корегування для впровадження іiі для веслувальників високої кваліфікації інших видів веслування. Проблема спеціальної фізичної підготовки веслувальників високої кваліфікації потребує поглибленого дослідження. Розробка програми тренувань $є$ різноманітною та багатогранною і підходить не для кожного спортсмена, тому під час розробки треба враховувати індивідуальні особливості стану спеціальної силової і функціональної підготовленості веслувальників та не наражати їх на перетренованість.

\section{ЛІТЕРАТУРА}

1. Платонов В.Н. Двигательные качества и физическая подготовка спортсменов. Москва : Спорт, 2019. $656 \mathrm{c}$.

2. Платонов В.Н. Периодизация спортивной тренировки. Общая теория и ее практическое применение. Киев : Олимп. лит., 2013. 624 с.

3. Дьяченко А. Совершенствование специализированной направленности тренировки гребцов-академистов высокого класса, ориентированной на развитие базовых компонентов выносливости с учётом критериев аэробного (вентиляторного) и анаэробного (лактатного) порогов. Педагогіка, психологія та медико-біологічні проблеми фізичного виховання і спорту : зб. наук. праць. Харків. 2002. № 8. С. 64-71.

4. Довгодько I., Дяченко А. Підвищення ефективності функціонального забезпечення спеціальної витривалості під час передстартової підготовки у веслуванні академічному. Теорія $i$ методика фізичного виховання і спорту. 2016. № 1. С. 67-71.

5. Дьяченко А., Лысенко Е., Виноградов В. Функциональное обеспечение специальной выносливости в циклических видах спорта (на материале академической гребли). Наука в олимпийском спорте. 2014. № 3. С. 38-44.

6. Дьяченко А.Ю., Федотов А.С. Специализированная оценка работоспособности, как основополагающий фактор формирования специальной выносливости гребцов-акдемистов высокого класса. Физическое воспитание студентов творческих спеціальностей : сб. научн. тр. Харьков. 2002 . № 3. C. 8-18.

7. Лысенко Е.Н. Прогнозирование физической работоспособности спортсменов по реакции кардиореспираторной системы при нагрузках аэробного характера. Вісник Запорізького національного університету. Біологічні науки. 2011. № 2. С. 87-97.

8. Довгодько I., Русанова О, Дяченко А. Аналіз впливу швидкої кінетики реакції кардіореспіраторної системи на ефективність функціонального забезпечення спеціальної роботоздатності веслуваль- 
ників. Молодіжний науковий вісник Східноєвропейського національного університету імені Лесі Украйнки. Фізичне виховання і спорт. 2018. № 29. С. 157-164.

9. Дяченко А.Ю., Кун Сянлинь. Контроль і моделювання навантажень в умовах компенсованого стомлення в процесі спеціальної фізичної підготовки веслярів. Фізичне виховання: теорія і практика. Часопис кафедри теорії і методики фізичного виховання, адаптивної та масової фізичної культури. Полтава. 2018. № 4. С. 65-69.

\section{REFERENCES}

1. Platonov V. N. (2019) Dvigatelnye kachestva i fisicheskay podgotovka sportsmenov [Motor qualities and physical training of athletes]. Moscwa: Sport, $656 \mathrm{~s}$.

2. Platonov V. N. (2013) Periodizatiya sportivnoy trenyrovki. Obshay teoriy i ye pratcicheskoe primineniye [Periodization of sports training. General theory and its practical application]. Kiev. Olymp. lit. $624 \mathrm{~s}$.

3. Dyachenko A. (2002) Sovershenstvovanye spezialezirovanoy napravlenosty trenyrovky grebtsov-akademystov vyesokogo klasa, orientirovanoy na razvitie bazovih komponentov vinoslivosty s uchetom kriteriev aerobnogo (ventilytornogo) i anaerobnogo (laktatnogo) porogov [Improving the specialized focus of training high-class rowers, focused on the development of basic components of endurance, taking into account the criteria of aerobic (ventilatory) and anaerobic (lactate) thresholds]. Pedagogika, psihologiya ta medico-biologichny problem fizychnoho vykhovannya i sportu: zb. nauk. prats'. Harkiv. № 8. S. 64-71.

4. Dovgodko I., Dyachenko A. (2016) Pidvisheny efektivnosty funkzionalnogo zabezpecheny spezialnoy vitrivalosty pid chas predstartovoy pidgotovky u vesluvany akademichnomu [Improving the efficiency of functional support of special endurance during pre-start training in academic rowing]. Teoriya i metodyka fizychnoho vykhovannya i sportu. № 1. S. 67-71.

5. Dyachenko A., Lysenko E., Vinogradov V. (2014) Funkzionalnoe obespechenye spezialnoy vinoslivosty vziklicheskih vidah sporta (na material akademicheskoy grebli) [Functional support of special endurance in cyclic sports (on the material of rowing)]. Nauka v olimpiyskom sporte. № 3. S. 38-44.

6. Dyachenko A. Y., Fedotov A. S. (2002) Spezialisirovanay ozenka rabotasposobnosty, kak osnovopologayushiy factor formirovaniya spezialnoy vinoslivosty grebzov-akademystov visokogo klasa [Specialized assessment of performance as a fundamental factor in the formation of special endurance of high-class academic rowers]. Physical Fizicheskoe vospitanye studentov tvorcheskih spezialnostey: zb. nauk. prats'. Harkiv. № 3. S. 8-18.

7. Lysenko E. N. (2011) Prognosirovaniye fizicheskoy rabotasposobnosty spotrsmenov po reakziy kardiorespiratornoy sistemy pri nagruzkah aerobnogo haraktera [Prediction of physical performance of athletes by the reaction of the cardiorespiratory system under aerobic loads]. Visnik Zaporizkogo nazionalnogo universitetu. № 2. S. 87-97.

8. Dovgodko I., Rusanova O, Dyachenko A. (2018) Analiz vplivu shvidkoy kinetiki reakzii kardiorespiratornoy sistemy na efektivnisty funkzionalnogo zabezpecheny spezialnoy robotozdatnosty vesluvalnikiv [Analysis of the influence of rapid reaction kinetics of the cardiorespiratory system on the effectiveness of the functional support of the special performance of rowers]. Molodigny naukoviy visnik Shidnoevropeyskogo universbtetu imeni Lesi Ukrainky. Fizychne vykhovannya i sport. № 29. S. 157-164.

9. Dyachenko A. Y., Kun Xianlin. (2018) Kontroly i modeluvanny navantageny v umovah komleksnogo stomlenny v prozesi spezialnoy fizichnoy pidgotovky veslyriv [Control and modeling of loads in the conditions of compensated fatigue in the course of special physical training of rowers]. Chasopis kafedry teoriyi i metodyki fizychnoho vykhovannya, adaptivnoi ta masovoi fizychnoy kultury. Poltava. № 4. $152 \mathrm{~s}$. 